\title{
Agriculture as a Tool to Boost Economy Post Covid-19 Pandemic
}

\section{Bilal Ahmad Sheikh, Omar Fayaz Khan and Sudhakar Dwivedi*}

Sher-e-Kashmir University of Agricultural Sciences and Technology of Kashmir, Jammu, 180009, JEK, India

*Corresponding author: dwivedi.sudhakar@gmail.com

Received: 07-09-2020

Revised: 22-10-2020

Accepted: $29-11-2020$

\section{ABSTRACT}

Farming is a significant branch for creation of food to the human population, as well as provides different crude materials like textile, tobacco, leather, and so forth, additionally, agribusiness understands an overflow of items, which are sent out to the world market and makes benefit. The assertion of agribusiness creation is the impression of overall economy and the level of innovation in handling industry and the coordination with the establishments and projects of socio-political framework. Agricultural production is a basic recourse for food items and counteraction of ailing health of total populace. In ongoing many years, the expected commitment of agriculture to financial development has been a subject of much controversy among advancement market analysts. While some contented that agriculture sector Leeds towards development of economy, others emphatically differ and contend for an alternate way. Exploiting ongoing turns of events, this paper re-examines the available literature regarding agriculture and will explore information that whether agriculture could serve as an engine to boost economic growth post COVID-19 Pandemic. Results from the available literatures regarding agriculture are explained in conclusion.

Keywords: Agriculture, creation, economy, country improvement, public pay

The possible commitment of Agriculture to financial development has been an on-going subject of much discussion among advancement business analysts. All things considered, ongoing exact examinations have yielded blended and some of the time clashing proof and there remains an absence of agreement on the impact of farming on monetary development. While a few specialists battle that agrarian improvement is a precondition to industrialization and monetary development, others emphatically differ and contend for an alternate way. A few creators contend that development in the general economy relies upon the improvement of the farming area (Schultz, 1964; Gollin, Parente, and Rogerson, 2002). Johnston and Mellor (1961) see that agribusiness adds to financial development and advancement through five between sectored linkages. The areas are connected by means of: (I) supply of excess work to firms in the modern area; (ii) supply of nourishment for homegrown utilization; (iii) arrangement of market for mechanical yield; (iv) supply of homegrown reserve funds for modern speculation; and (v) supply of unfamiliar trade from farming fare income to back import of middle and capital products. In 5 augmentations to these five direct market-based linkages, Timmer (1995) likewise underscored the significance of roundabout non-market linkages that improves the nature of

How to cite this article: Sheikh, B.A., Khan, O.F. and Dwivedi, S. (2020) Agriculture as a Tool to Boost Economy Post Covid-19 Pandemic. Agro Economist - An International Journal, 7(2): 139-144.

Source of Support: None; Conflict of Interest: None 
the significant creation factors (work and capital). He sees that Agriculture by implication adds to monetary development through its arrangement of better caloric supplement admission by poor people, food accessibility, food value security, and destitution decrease. He contended that the job of Agriculture has been disparaged due to information impediments that block express quantitative investigations of the circuitous impacts of agribusiness' commitments to capital and work proficiency and absolute factor efficiency. Consequently, Timmer upheld for "another demonstrating approach that can be applied to a wide cross-part of time arrangement information at the public level.

The improving profitability in farming is coordinated especially through proficient water and soil the executives rehearses, crop sustenance and security from irritations and illnesses. This program needs uphold from public and International association in food and Agriculture. The normal pace of development of farming creation in Serbia, toward the start of the 21 st century, is $1.3 \%$ of total assets, with predominant plant creation. This pattern in farming creation in Serbia is in concurrence with worldwide forecast that addresses of issues of the total populace for food in 2050 will be important to build crop yields by $1.3 \%$ per annum (Fischer et al., 2014). The reason for concentrated agribusiness has remained the choice of new cultivar and crossovers of plant species and types of homegrown creatures, which had more prominent expected profitability. Today, the fundamental undertaking is the formation of high-yielding assortments and cross breeds, which are the reason for expanding food creation (Fridman and Zamir, 2012). Anyway in created Country inside farming creation, the prevailing job is creation of homegrown animals and better market linkage. The assertion of farming creation is the impression of explanation of in general economy and the level of innovation in handling industry also level of coordination with the organizations and projects of socio-political framework. Environmental change is one of the upsetting issues that is at present occurring, and as of now expected a worldwide temperature alteration later on is more noteworthy than recently anticipated. Winning perspective on researchers that we presently face an unavoidable expansion in worldwide temperature and that is incredible likelihood that environmental change

Print ISSN : 2350-0786 has just happened. With the danger of atmosphere changes, an ever increasing number of districts of the world are additionally in danger of dry season and desertification. To alleviate the negative impacts of environmental change, it is important to exploit current logical information and grow new ones (Lin et al. 2005). Improved water system practices will help monitor water and ensure weak land. Steady and radioactive isotopes can be utilized as "labels" at the atomic level to screen how plants utilize fundamental supplements just as to contemplate crop development and supplement necessities to expand yields, while moderating water and forestalling further debasement of negligible grounds. In monetarily created nations, agribusiness is portrayed by high profitability, which depends on present day specialized and innovative methods and strategies for creation, at that point a serious level of association adjusted to the kind of Agricultural creation and combination with current frameworks of handling and the appearance available of completed items, a further and item arrangement and pay and benefit (Knezevic and Micanovic, 2013).

The present study is an attempt to find out whether agriculture could serve as an engine to boost economic growth post COVID-19 pandemic.

\section{MATERIALS AND METHODS}

The present study is based on secondary data, collected from different online as well as offline journals, books and newspapers related to agriculture sector of different nations. Hence the present study re-examines the available literature regarding agriculture and will explore information that whether agriculture could serve as an engine to boost economic growth post COVID-19 Pandemic.

\section{RESULTS AND DISCUSSION}

\section{Agriculture for monetary and social security}

Agriculture can add to development of economy and modernization of society, in view of its plenitude of assets and its capacity to move excesses to the mechanical area. Harvest creation also domesticated animals creation should be more escalated in the reason to fulfill request of expanding total populace for food, what require extra ventures of 80 billion Euros consistently for diminishing 
neediness. Rural ventures can create benefits as expanding profitability and food accessibility, work of individuals, diminishing neediness, presenting and move current innovation and admittance to capital and markets. In farming most assets are utilized for food creation and have job as a single direction stream of assets towards the modern creation, in view of frail opportunities for exchange. Agriculture is significant for food and for various other purposes. Agribusiness speaks to wellspring of gathering for new interest in ind ustry and adds to the expanding market for industry items. Moreover Agriculture supplies essential items for preparing industry. Additionally, agribusiness profit in fare accommodate installment of imported merchandise (Timmer, 2002). The effect of agribusiness in GDP depends from linkage of Agriculture and innovation, HR which straightforwardly backing to cultivate efficiency and diminishing expenses, too association farming and innovation. The essentialness of Agriculture share in GDP likewise, associated with macroeconomic arrangements through measure of tax assessment from food makers, dealers and exporters, by interest in delivering mechanical developments and interest in country salaries to create social advancement and framework. The industrialized administration of Agriculture alludes to the administration framework that set up agrarian bases with undertakings engaged with rural item preparing, deals or specialized assistance as driving power and lead ranchers in the rural creation bases to set out on specific creation of farming items. This administration can successfully take care of the linkage issue between Agricultural families of limited scope activity and homegrown and unfamiliar enormous business sectors, increment the worth added of farming by lengthening the modern chain, and improve the administration effectiveness.

The viewpoint of the provincial economy improvement the one of the previous type of association of Agricultural creation dependent on cooperatives ranch, today is less and less present. The explanations behind this are differed, and among them showed unfruitful presence, accentuated exchange and organization capacities, inappropriate getting for venture, low profitability results and others. On this premise, the agreeable couldn't satisfy its essential capacity in light of a legitimate concern for individuals. Likewise, the intricate possession structure of resources in cooperatives disturbed their restoration. Rather emerge new types of association of little and medium-sized endeavors, which affect the advancement of social relations and financial turn of events. It is sure that the vital relationship of makers to fortify creation wellbeing, commitment to satisfying the needs of the market for the amount and nature of items. Regardless of whether the little land holders are combined and expanded later on so the plot or to bigger organizations purchasing or leasing land plots augmented later on creation, to making better embraced for higher efficiency. Little makers themselves can barely meet the models of intensity in farming creation. All ranches as indicated by their ability to play out the creation and control as in plant and animal creation, which is a component of a more significant level of buyer security and sanitation. The key for food and sustenance security is Agricultural speculation by ranchers or the public area. The venture can add to expanding efficiency at the ranch creation and can build amount and nature of food available, decrease cost and more grounded association among rustic and metropolitan buyers. The improving of public ventures and good arrangement animate development in the agrarian area is conceivable accomplish through the open door for ranch speculation without monetary middle people, and the possibility to acquire high paces of profit for public speculations that right for metropolitan inclination (Timmer, 2002). The farming development have share in financial development and direct commitment to development in GDP. The logical potential that we have placed into activity improving the degree of mechanical improvement of the economy, most importantly, overcoming any issues among science and economy (Mićanović et al. 2011). Motivators ought to be given to as per the predicted portions and relevant norms in assembling, regardless of whether it is a plant animal varieties or types of homegrown creatures just as items from them. Additionally, the improvement ought to be fortified on the off chance that the expansion of creation, which is needed for legitimate removal of waste (compost in developing creatures), biomass (in the development of grains, and so on) In this way compost delivered can be utilized in the sustenance of the plants, which can't be more prominent than $170 \mathrm{~kg} \mathrm{ha}^{-1}$ every year. 


\section{Growth in agriculture}

Fortifying Agriculture in the European Union depends on: improving the seriousness of the rural area, improving the nature of rural items and ecological insurance, advancement of farmland variety, and legitimization for spending the EU financial plan for agribusiness. In the European Union, of the all out Agriculture, the creation of $75 \%$ is accomplished in 7 nations as follows: France $(18 \%)$, Germany $(14 \%)$, Italy $(13 \%)$, Spain $(10 \%)$, the UK $(8 \%)$, the Netherlands $(7 \%)$ and Poland (5\%). France has become a main maker and exporter on account of the impact of motivating forces of Agricultural creation, in long term. The France, after fare of farming items was the third on the planet, of which the main fare items were wheat, poultry, dairy items, meat, pork, champagne burgundy. In France, the $3.8 \%$ of the dynamic populace is utilized in agribusiness and the food business had a portion of $4.2 \%$ of GDP. France after fare of Agricultural items was the third on the planet, of which the main fare items were wheat, poultry, dairy items, meat, pork, champagne burgundy In the model of the EU agrarian gave market mediation to items that are critical to food security and income maker, for example, sugar, wine, olive oil, and so forth, Wherein is completed unfamiliar assurance intercession purchasing and different types of item withdrawal from the market, and backing utilization and creation of specific items. Farming and food industry in the EU assume a significant part in guaranteeing the soundness of the populace, in rustic turn of events and ecological insurance. About 500 million EU shoppers spend almost a fourth of their income on food. In the farming creation is utilized about $2 \%$ of the workforce, which adds to over $4 \%$ of the GDP of the EU, and the food business are utilized, about $3 \%$ of the workforce, which adds to over $3 \%$ of the GDP. The possibilities of the food area are essentially higher in the EU for work $(20 \%)$ and in this way a superior portion of GDP (about 10\%). Regarding the current monetary circumstance builds up an arrangement of association of farming creation, transport, and joint technologies of dispatch of rural item (Latacz-Lohmann and Hodge, 2001) Today's volume of Agricultural creation in Serbia is at the normal degree of agricultural nations, which is incomprehensible given the current expert human and characteristic assets. This is expected, outdated nature and absence of specialized assets, horrible age structure and the quantity of rural populace, just as the naiveté and inadequacy of returnees from metropolitan zones in Agriculture (Micanovic and Zecevic, 2012). Additionally, a critical factor influencing the upkeep of stagnation in Agricultural creation is the presence of rivalry, the presence of directors in comes to building creation without sufficient instruction and experience, deficient interest in science and backing logical and midprofession programs, in the event that they exist at the degree of examination minus any additional execution of the defined ends and the program of measures for improvement of agribusiness (Fridman and Zamir, 2012). Additionally, a huge hindrance factor is the absence of venture and existing costly interest in farming the outcomes acquired for the nations in Latin America are like those in Asia. The experimental proof shows that farming assumes a significant job in invigorating since quite a while ago run GDP development in three nations (Brazil, Colombia, and Mexico). Specifically, the finding for Brazil isn't amazing when we consider the wonderful extension in Brazilian Agricultural creation and fares in ongoing 18 decades. As indicated by late information from the Brazilian Ministry of Agriculture, the countries' agrarian fares expanded from US\$24.8 billion to US\$49.4 billion somewhere in the range of 2002 and 2006 (i.e., a 99 percent expansion in five years). Brazil contends with the US and significant EU agrarian makers for an eminent portion of the world market for a few rural wares. For instance, Brazil is a top maker and exporter of meat, ovens, espresso, soybeans and oilseeds, sugar, and sugar-based ethanol. The current examination shows that farming has made a critical commitment to Brazilian monetary development.

\section{CONCLUSION}

Agriculture can contribute to growth of economy and modernization of society, because of its abundance of resources and its ability to transfer surpluses to the industrial sector. Crop production as well livestock production needs to be more intensive in the purpose to satisfy demand of increasing world population for food. The intensification of agricultural production is based on the development and application of new technologies of cultivation of plants and animals, nutrition, harvest, storage and 
marketing. Increasing of production in agriculture sector in a sustainable way is today a realistic target. The future progress of agriculture will be based on using of new technologies in farmers production and developing an open market environment to make the resulting production as profitable to producers and generate employment opportunities in other sectors. Hence by analyzing the available literature from different geographies of world regarding agriculture, it is found that agriculture is an engine of economic growth and could serve as a tool to boost economic growth post COVID-19 Pandemic.

\section{REFERENCES}

Awokuse, T.O. 2008. "Trade openness and economic growth: Is growth export-led or import-led?" , Applied Economics 40: 161-173.

Banja Luka, Republic of Srpska, Ministry of Science and Technological Development of the Republic of Slovenia and the Association of Inventors, pp. 41-49.

Barro, R. and Lee, J-W. 1994. "Sources of economic growth." Carnegie Rochester Conference Series on Public Policy, 40: $1-46$.

Caporale, G. and Pittis, N. 1997. "Causality and forecasting in incomplete system." Journal of Forecasting, 16: 425-437.

Cvijanović, D., Subić, J. and Vasile, A.J. 2014. Sustainable agriculture and rural development in terms of the republic of serbia strategic goals realization within the danube Region" - rural development and (un)limited resources- Tara Belgrade, 5-7 June 2014. Proceeding pp.580-596.

Datt, G. and Ravallion, M. 1998. "Farm productivity and rural poverty in India." Journal of Developmental Studies, 34(4): 62-85.

De Brauw, A., Huang, J. and Rozelle, S. 2004. “The Sequencing of Reform Policies in China's Agricultural Transition." Economics of Transition, 12(3): 427-65.

Dickey, D.A. and Fuller, W.A. 1979. “Distribution of the estimators for autoregressive time series with a unit root." Journal of the American Statistical Association, 74: 427-431.

Dowrick, S. and Gemmell, N. 1991. “Industrial catching up and economic growth: a comparative study across the world's capitalist economics." Economic Journal, 101: 263-276.

Echevarria, C. 1997. "Changes in sectoral composition associated with economic growth." International Economic Review, 38(2): 431-452.

Edwards, S. 1993. "Openness, trade liberalization, and growth in developing countries." Journal of Economic Literature 31: 1358-1393. Engle, R.F.
Fardmanesh, M. 1991. "Dutch disease economics and the oil syndrome: An empirical study." World Development, 19(6): 711-17.

Fei, J. and Ranis, G. 1961. "A theory of economic development." American Economic Review, 51(4): 533-565.

Fischer, T., Byerlee, D. and Edmeades, G. 2014: Crop Yields and Global Food Security: Will Yield Increase Continue to Feed the World: ACIAR Monograph 158.

Frankel, J. and Romer, D. 1999. "Does trade cause growth?" American Economic Review, 89(3): 379-399.

Gardner, B. 2005. "Causes of rural economic development." Proceedings of the $25^{\text {th }}$ International Conference of Agricultural Economists, pp. 21-41.

Fridman, E. and Zamir, D. 2012. Next-generation education in crop genetics. Curr. Opin. Plant Biol., 15: 218-223.

Gemmell, N., Lloyd, T. and Mathew, M. 2000. “Agricultural growth and intersectoral linkages in developing economy." J. Agric. Econ., 51(3): 353-370.

Gollin, D., Parente, S.L. and Rogerson, R. 2002. "The role of agriculture in development." American Economic Review, 92(2): 160-164.

Gollin, D., Parente, S.L. and Rogerson, R. 2007. “The food problem and the evolution of international income levels." Journal of Monetary Economics, 54: 1230- 1255.

Granger, C.W.J. 1987. “Co-integration and error correction: representation, estimation and testing." Econometrica, 55: 251-276.

Helpman, E. and Krugman, P. 1985. Market structure and Foreign Trade, Cambridge, MA: MIT Press.

Humphries, H. and Knowles, S. 1998. “Does agriculture contribute to economic growth? Some empirical evidence." Applied Economics, 30(6): 775-781.

Hwa, E.C. 1988. "The contribution of agriculture to economic growth: some empirical evidence." World Development, 16(11): 1329-1339.

Johansen, S. and Juselius, K. 1990. “Maximum likelihood estimation and inference on cointegration with applications for the demand for money." Oxford Bulletin of Economics and Statistics, 52: 169-210.

Johnston, B. and Mellor, J. 1961. "The role of agriculture in economic development." American Economic Review, 51(4): 566-593.

Jones, C.I. 1998. Introduction to Economic Growth. Norton, New York.

Jolánkai M. and Birkás, M. 2007. Global Climate Change Impacts on Crop Production in Hungary. Agriculturae Conspectus Scientificus, 72(1): 17-20.

Jorgenson, D. 1961. "The development of a dual economy." Economic Journal, 282: 209-334.

Kogel, T. and Prskawetz, A. 2001. "Agricultural productivity growth and escape from the Malthusian trap." Journal of Economic Growth, 6: 337-357. 
Knezevic, D. and Micanovic, D. 2013. The role of science to development of economy and agriculture. Thematic Proceedings. International scientific conference, "Sustainable agriculture and rural development in terms of the republic of Serbia strategic goal realization within the Danube region".

Knezevic, D., Kondic, D., Markovic, S., Micic, N. and Đuric, G. 2013. Breeding for crop improvement. Fourth International Scientific Symposium "Agrosym Jahorina 2013", Editoral in Chief: Dušan Kovačević, 03-06. October 2013. Jahorina, Proceeding, pp. 441-448.

Knezevic, D., Rosandic, A., Kondic, D., Radosavac, A. and Rajkovic, D. 2016. Impact of quality of grain wheat on food value. Növénytermelés, 65: 99-102. Suppl.1.

Kwiatkowski, D., Phillips, P.C.B., Schmidt Shin, P., Y.C. 1992. "Testing the null hypothesis of stationarity against the alternative of a unit-root - How sure are we that economic time-series have a unit-root." Journal of Econometrics, 54(1-3): 159-178.

Latacz-Lohmann, U. and Hodge, I. 2001. European agrienvironmental policy for the $21^{\text {st }}$ century. The Australian Journal of Agricultural and Resource Economics, 47(1): 123-139.

Lewis, W.A. 1954. "Economic development with unlimited supplies of labour." The Manchester School, 22(1): 139191.

Lin, J.Y. 1992. "Rural reforms and agricultural growth in China." American Economic Review, 82(1): 34-51.

Lin, E., Xiong, W., Ju, H., Xu, Y., Li, Y., Bai, L. and Xie, L. 2005. Climate change impacts on crop yield and quality with $\mathrm{CO}_{2}$ fertilization in China. Phil. Trans. R. Soc. B., 360: 2149-2154.

Matsuyama, K. 1992. “Agricultural productivity, comparative advantage, and economic growth", Journal of Economic Theory, 58(2): 317-334.

Menkovska, M., Brankovic, G., Pajic, V., Momirovic, G.S. and Knezevic, D. 2015. Associations between nutritional composition and farming type of organically and conventionally grown cereals. Natural Science and Discovery, 1(4): 97-101.

Micanovic, D. and Zecevic, V. 2012. Science and Economy. Tematic Proceedings. International Scientific MeetingSustainable agriculture and rural development in terms of the Republic of Serbia strategic goals realization within the danube region Preservation of rural values. Dec, 6-8 2012, pp.189-205 (CD-ROM). Inst. of Agric. Economics, Belgrade.
Mićanović, D. Knežević, D. and Zečevič, V. 2011. Transfer of knowledge and technologies in the function of economic development. Proceedings of the scientific conference Technological inovacijegenerator economic development.

Morley, B. 2006. "Causality between economic growth and immigration: An ARDL bounds testing approach." Economics Letters, 90: 72-76.

Okonkwo, I.C. 1989. “The erosion of agricultural exports in an oil economy: The case of Nigeria." Journal of Agricultural Economics, 40(3): 375-84.

Olsson, O. and Hibbs, D.A. 2005. "Biogeography and longrun economic development." European Economic Review, 49(4): 909-938.

Pachepsky, E., Bown, J.L., Eberst, E., Bausenwein, U., Millard, P., Squire, G.R. and Crawford, J.W. 2007. Consequences of intraspecific variation for the structure and function of ecological communities Part 2: Linking diversity and function, Ecological Modelling, 207: 277-285.

Park, A., Jin, H., Rozelle, S. and Huang, J. 2002. “Market emergence and transition: arbitrage, transaction costs, and autarky in China's grain markets." American Journal of Agricultural Economics, 84(1): 67-82.

Pesaran, M.H., Shin, Y. and Smith, R. 2001. "Bounds testing approaches to the analysis of level relationships." Journal of Applied Econometrics, 16: 289-326.

Rosandic Anja and Knezevic, D. 2014. Economic aspects sustainability of the natural and social resources. 65th Anniversary of the Institute of Agricultural Economics Belgrade. International Scientific Conference.

Ruttan, V. 2000. Technology, Growth and Development - An Induced Innovation.

Timmer, C.P. 2002. Agriculture and Economic Growth. In Bruce Gardner and Gordon Rausser, eds., Handbook of Agricultural Economics, Vol. IIA. Amsterdam: North Holland, pp. 1487-1546.

Topola, December 5-7 th 2013 , pp. 158-174. Institute of Agricultural Economics, Belgrade. 